\title{
O QUE É UM CLÁSSICO: ALGUMAS CONSIDERAÇÕES
}

\author{
What is a Classic: Some Considerations
}

\author{
Roberto Akira Goto ${ }^{1}$
}

RESUMO: As considerações que compõem este ensaio orientam-se por uma abordagem do ser do clássico, e nessa medida apontam para uma metafísica do clássico. Mas nada implicam de sistemático: trata-se, basicamente, da condição humana. São apontamentos tomados ao sabor do pensar - sabor que deve remeter não só ao acaso, mas também ao tempero adicionado por apelos e mesmo necessidades da circunstância.

PALAVRAS-CHAVE: Clássico; Condição humana; Cultura; Pensamento; Circunstância.

ABSTRACT: The considerations that compose this essay orient themselves by an approach about the being of the classic, and, in this sense, they indicate to a metaphysics of the classic. However, they are not systematic: their subject, basically, is the human condition. These considerations are annotations taken by the thinking stream - stream that must to remit not only to hazard, but also to the flavour added by the appeals and even the needs of the circumstance.

KEYWORDS: The classic; Human condition; Culture; Thinking; Circumstance.

Em princípio, o que define - ou deveria definir - um clássico é ele mesmo. Por outras palavras, o ser do clássico se exprime por uma tautologia: um clássico é um clássico. Se ainda houvesse um mundo comum, no sentido proposto por Hannah Arendt, essa autodefinição seria suficiente. No entanto, como o que há é sociedade de massas - na qual "seres humanos $[. .$.$] se relacionam ainda uns aos outros", porém tendo perdido "o mundo$ outrora comum a todos eles"2 -, e o que se procura, mesmo nos círculos intelectuais, é assegurar "uns aos outros o direito de nos refugiar em nossos próprios mundos de significado" ${ }^{3}$, sempre se pergunta “por que?”, “para que?”, sobretudo “para que serve?".

\footnotetext{
${ }^{1}$ Doutor em teoria e história literária pela Universidade Estadual de Campinas (UNICAMP). Professor no Departamento de Filosofia e História da Educação na Faculdade de Educação da Universidade Estadual de Campinas (UNICAMP). E-mail: goto@unicamp.br

${ }^{2}$ Cf. ARENDT, Hannah. Entre o passado e o futuro. Trad. Mauro W. Barbosa de Almeida. São Paulo: Perspectiva, 1972, p. 126.

${ }^{3}$ Ibidem, p. 132.
} 
Dessa forma, a questão se desloca do que é para o que vale: do ser do clássico para o seu valor. É sintomático, quanto a isso, que Italo Calvino, após encadear as razões que justificariam a leitura dos clássicos, acabe por dizer que é melhor lê-los do que não lê-los, propondo uma espécie de postulado valorativo, que dispensa fundamentação: é preciso admitir que é mais valioso ler um clássico que não lê-lo - para, então, lê-lo.

Um argumento desse tipo apenas confirma que, na prática, a tautologia "o clássico é um clássico" não tem como sustentar-se, como manter-se em pé sobre as próprias pernas (que é o que se espera, redundantemente, de toda tautologia). O próprio fato de se precisar argumentar a favor da leitura dos clássicos demonstra a fragilidade da tautologia, evidenciando que não lhe é facultado expor-se impunemente, ou seja, que não se pode mais dizer "um clássico é um clássico" sem que haja questionamento e contestação. O arrazoado de Calvino é uma resposta a essa demanda, inclusive quando se manifesta em termos de cobrança de serventia e utilidade. Num primeiro momento, ele parece disposto a satisfazê-la: diz, então, que "os clássicos servem para entender quem somos e aonde chegamos". Mas, justamente ao argumentar que é melhor ler os clássicos que não lê-los, o escritor italiano dispõe: “não se pense que os clássicos devem ser lidos porque 'servem' para qualquer coisa". Citando Cioran para tentar convencer os que podem objetar que "não vale a pena tanto esforço" (o de ler os clássicos), lembra: "Enquanto era preparada a cicuta, Sócrates estava aprendendo uma ária com a flauta. 'Para que lhe servirá?', perguntaram-lhe. 'Para aprender esta ária antes de morrer."4

O postulado valorativo de Calvino não tem, portanto, o condão de satisfazer o desafio da serventia, inclusive na medida em que, para ser aceito, depende da suspensão ou supressão do "para que serve". Confirma-se, mais uma vez, a inocuidade ou inanidade da tautologia, o fato de que, para todos os efeitos, o clássico não tem chão, o que se pode comprovar seguidamente pela prática escolar que corresponde ao ensino dos clássicos: se esse ensino implica, cada vez mais, que os estudantes sejam convencidos do valor e da importância dos clássicos, se o estudo deles é vivido como um trabalho tedioso e forçado, imposto arbitrariamente, isso não mais que reitera o óbito do clássico, que só existiria na forma de um zumbi usurpador da vida, pois um clássico autêntico, na acepção daquela tautologia, seria aceito e estudado simples e puramente por ser o que é, por valer o que

\footnotetext{
${ }^{4}$ Cf. CALVINO, Italo. Por que ler os clássicos. In: __. Por que ler os clássicos. Trad. Nilson Moulin. 5. reimpr. São Paulo: Companhia de Bolso, 2016, p. 16. Como o próprio título explicita, a obra de Calvino debruça-se sobre os clássicos literários. O presente ensaio abarca outras artes (como a música) e a cultura de modo geral, na medida em que tenta pensar o ser do clássico.
} 
vale, tout court. Assim, na prática - sobretudo nessa prática educacional, especialmente a escolar -, tudo conspira não só contra o cultivo dos clássicos, mas também contra o reconhecimento de sua mera existência.

No entanto, os clássicos não apenas existem como também vivem, isto é, existem como elementos vivos da cultura - de uma cultura viva, ela própria -, e isso pode e talvez deva ser dito segundo o mesmo espírito com que Galileu Galilei disse eppur si muove, num estado de coisas (um certo status quo cultural) semelhante ao dele, ao mesmo tempo em que bastante pior, na proporção em que o papel inquisitorial, exercido difusamente pelas massas, no caso de nossa contemporaneidade, se amplia quantitativamente e se intensifica qualitativamente. Cabe, portanto, falar não só do ser do clássico, mas também de sua vida, podendo-se acrescentar àquela tautologia que um clássico é um clássico na medida em que é vivo, ou que um clássico vive como clássico.

\section{II}

Se algo ou alguém dura e permanece na cultura, ao longo do tempo, não desaparecendo, portanto, no esquecimento, é porque o que diz cala fundo nos corações e mentes, o que diz é relevante e consistente - e o é não para esse ou aquele indivíduo, não para esse ou aquele grupo, mas para o espírito humano de modo geral. E se é relevante e consistente dessa forma, é porque (re)fere a concreta condição humana.

O que é ou se torna clássico não se reduz a ondas culturais passageiras, nem mesmo se compara a correntes culturais avassaladoras. Na realidade, acontece de um clássico nadar contra a corrente e nela submergir, o que significa que o clássico tanto não é o que emerge na crista da onda, não é o que vive aparecendo a qualquer pretexto, como tampouco é o que arrasta multidões atrás de si. Frequentemente, aliás, ele é discreto e silencioso, é conhecido e lido por poucos, tidos equivocadamente como uma ou "a" elite.

O que define um clássico não é o fato de ele empolgar ou arrastar multidões, mas o de afetar a sensibilidade e a inteligência de cada um em profundidade, e mesmo de propiciar novas sensibilidades e mentalidades, de criar novos modos de sentir e de pensar ${ }^{5}$. “Clássico" não é sinônimo de "célebre"; a palavra pouco ou nada tem a ver com a fama

\footnotetext{
${ }^{5} \mathrm{O}$ que é congruente com o fato de que as leituras de clássicos são formativas, "no sentido de que dão forma às experiências futuras, fornecendo modelos, recipientes, termos de comparação, esquemas de classificação, escalas de valores, paradigmas de beleza". Feitas na juventude, essas leituras reverberam nas releituras da maturidade, em que "acontece reencontrar aquelas constantes que já fazem parte de nossos mecanismos interiores e cuja origem havíamos esquecido" (cf. Calvino, op. cit., p. 10). Por outro lado, se "os livros permaneceram os mesmos (mas também eles mudam, à luz de uma perspectiva histórica diferente), nós com certeza mudamos, e o encontro é um acontecimento totalmente novo" (ibidem, p. 11).
} 
dos ídolos das massas. Tampouco "universal", em seu caso, significa ser popular ou globalizado; consiste em ser dotado da potência de ser humanamente compreendido por qualquer humano habitante do planeta, ao mesmo tempo em que, por seu turno, o compreende, o envolve.

Isso implica a prática de uma metafísica do clássico, no sentido de pesquisar e afirmar uma essência do clássico, que condiciona e instrui sua recepção ou percepção. Significa, por exemplo, que Johann Sebastian Bach define-se como clássico (isto é, como um compositor cuja obra resistiu em sua integridade à ação corrosiva do tempo e destacouse de seu fluxo) não porque é condicionado, muito menos determinado pela audição de sua música - pois se ela for ouvida e sentida como qualquer outro tipo de música, é o caso de dizer que não se está ouvindo Bach, justamente como um clássico, mas como música de um compositor qualquer. É, inversamente, sua música que condiciona e exige uma certa audição, uma certa sensibilidade - a que lhe corresponde -, requerendo, portanto, uma correspondência do ouvinte ${ }^{6}$. E é ele, o clássico, que exige - o que significa, de certa forma, que a iniciativa parte dele, é ele o polo ativo.

Há, portanto, como que uma essência do clássico, que só se manifesta e só se realiza se e quando ela é correspondida por uma sensibilidade, uma mentalidade ou inteligência que, de alguma forma, foi educada e formada, mesmo criada e propiciada, suscitada pelo próprio clássico - concretamente, no caso de um J. S. Bach ou de um Ludwig Van Beethoven, pelas tantas vezes que o ouvinte se dispõe e se esmera em ouvi-lo, mergulhando em seu mundo, explorando-o compasso por compasso, acorde após acorde. Essa essência é simultânea à constituição do clássico, na medida em que algo ou alguém se torna clássico quando se constitui essencialmente no que é. Bach é um clássico na medida em que o ouço como ele é, não como qualquer outro, ou seja, na medida em que correspondo a - e correspondo-me com - sua especificidade, sua unicidade, sua essência, portanto.

Essa unicidade não impossibilita nem prejudica a multiplicidade de interpretações, pois é da essência do clássico possibilitar e solicitar múltiplas leituras, ou seja, cada clássico é único na medida em que admite e compreende, mesmo exige e abraça múltiplas

\footnotetext{
${ }^{6}$ Ao definir como clássicos os livros que "quanto mais pensamos conhecer por ouvir dizer, quando são lidos de fato mais se revelam novos, inesperados, inéditos", Calvino observa que "isso ocorre quando um clássico 'funciona' como tal, isto é, estabelece uma relação pessoal com quem o lê" - se "a centelha não se dá, nada feito" (ibidem, p. 12).
} 
leituras. Isso se dá justamente porque ele é vivo, e de uma maneira - ou numa amplitude - universal, enraizada em sua conexão com a condição humana.

\section{III}

A universalidade do clássico não é abstrata nem etérea, mas bastante concreta, viva: consiste no fato de exprimir um substrato humano, que transcende sua cultura de origem, possibilitando e potencializando o diálogo entre ela e outras culturas particulares. É uma universalidade que desafia e ultrapassa tanto o etnocentrismo quanto o relativismo, orgânica à medida mesma que, continuamente, se põe à prova no cotejo não raramente conflituoso entre as diferentes culturas étnicas. Quando um bengalês como Chanu, personagem do romance Um lugar chamado Brick Lane, de Monica Ali, menciona autores como Geoffrey Chaucer, Charles Dickens, Thomas Hardy, as irmãs Brontë e William Thackeray, além de David Hume, o faz para atestar sua capacidade intelectual, confrontando a "gente ignorante", na classe média londrina, que não entende nem cita esses autores $^{7}$ : sua atitude não só pressupõe a possibilidade de comunicação e diálogo entre as culturas como exprime uma resposta ao repto ${ }^{8}$ implícito de transcender diferenças e singularidades para compreender obras de outras culturas que não a sua.

Ao mesmo tempo, um clássico não é universal por sustentar esse ou aquele valor, por apresentar ou defender essa ou aquela moral, mas por propiciar ou mesmo propor que sejam debatidos, o que supõe como precondição que sejam dispostos numa situação dialógica, como a que se dá entre cristãos e judeus n'O Mercador de Veneza de Shakespeare.

Em algum aspecto ou nível dos dramas de Shakespeare, Macbeth é e age como escocês, Hamlet como dinamarquês, mas em geral e para o que importa, todos são e agem, "simplesmente", como humanos, e nessa medida é que são clássicos - ou nessa medida é que Shakespeare é clássico, é universal, por mostrar o humano nessas figuras. Trata-se do humano não só como fato, como realidade ou condição, mas também como valor, nesse sentido mesmo que extrapola e transcende o local e o nacional, por esse sentimento que nos leva a perguntar: se os estadunidenses ofendem brasileiros e outros ao monopolizarem o genitivo "americano", o que significa e o que vale ser americano?, o

\footnotetext{
${ }^{7}$ Cf. ALI, Monica. Um lugar chamado Brick Lane. Trad. Léa Viveiros de Castro. Rio de Janeiro: Rocco, 2004, p. 35 e 40.

${ }^{8}$ Em suma, Chanu (in)tenta responder ao etnocentrismo europeu (ou ocidental) em seu próprio terreno, dando o troco na mesma moeda: ele, originário de Bangladesh, interessa-se pela literatura e pela cultura britânicas, europeias - e as compreende -, mais que um inglês, um escocês, ou um europeu de modo geral.
} 
que isso diz da essência de cada um, assim como o próprio "brasileiro"? - o que significa e até que ponto se deve fazer questão de sê-lo? Em suma, ser ou não ser brasileiro, ser ou não ser americano não faz grande diferença, de fato (e em termos de valor), no que respeita ao ser, não afeta a essência de cada um. Mas ser ou não ser humano, sobretudo ser ou não ser tomado e reconhecido pelo outro como humano, isso faz toda a diferença, isso afeta, real e valorativamente, o ser de cada um.

Essa é uma lição que se pode aprender com e nos clássicos: a de que é possível abrir mão ou não fazer questão de identidades locais, regionais e nacionais, mas não se pode deixar de reivindicar a humanidade, mesmo com toda a miséria psicológica e moral que ela comporta - o trágico consistindo, no caso, em tomar posse da condição humana pelo que ela implica no sentido de se sofrer toda essa miséria não só como quem cai em desgraça, mas também como alguém que reivindica ser digno dela, de estar à altura, justamente, de sofrê-la, de assumi-la9.

\section{IV}

A universalidade do clássico requer e realiza a universalidade da cultura. Essa relação é de reciprocidade. Pode-se falar numa cultura universal, nesse sentido de uma cultura que está ao mesmo tempo aquém e além das culturas particulares - étnicas, locais, regionais, nacionais -, constituindo tanto as condições de possibilidade para que se comuniquem e dialoguem entre si quanto um patrimônio da humanidade, que as transcende, na medida em que tal cultura se deixa definir essencialmente pelo fato de referir, em última instância, o humano, de ser em tudo e por tudo a cultura humana, ou seja, a cultura própria do humano - no mínimo, a cultura a que cada um pode chamar e

\footnotetext{
${ }^{9}$ Trata-se aqui de considerar uma certa imagem que o trágico projeta de si, como reivindicação de dignidade: no que se tem e se lê como trágico, o destino é a moldura e a trama, ele frisa todas as condições adversas da ação humana, mas o propriamente trágico não decorre da simples manifestação do destino decorre da luta humana contra ele, da reivindicação de uma dignidade contra tudo que busca acachapar o humano, amassá-lo contra o chão, torná-lo mesmo chão e cão. O trágico consiste em o homem não se conformar com esse destino que lhe tira ou the nega a dignidade de dizer-se responsável por sua escolha e sua ação. Está nesse esforço do humano para mostrar-se digno de ser livre, quando tudo aponta para a escravização ou o determinismo: esforço inglório e fracassado - fracasso antevisto na inevitabilidade da vitória das forças e condições que negam a dignidade. No entanto, sabendo disso, o homem trágico insiste, desafia as forças adversas, revolta-se contra elas, obtém sua dignidade na forma do próprio fracasso: uma dignidade na derrota, na morte, na escravidão. A revolta trágica exprime o inconformismo do humano ante sua condição própria, ontológica, de ente sujeitado e subjugado por forças que o dominam e o escravizam e que ele não pode vencer: essa revolta é a afirmação de uma liberdade não só como ação (no sentido de libertação) mas sobretudo como condição - a do ser livre. É afirmar-se livre em e contra condições que the dizem que ele não é livre, que ele não tem escolha, que ele só pode entregar-se às forças que o escravizam, deixar-se subjugar por elas. O homem trágico, em suma, reivindica participação e protagonismo no conflito entre as forças cujo embate deve decidir seu destino: ele não se contenta em ser, segundo o provérbio africano, a grama pisada pelos elefantes em luta.
} 
aceder como sua porque ambos, ele e ela, são e/ou se concebem, no final das contas, humanos. A relação de reciprocidade implica que a cultura (humana) é universal na medida em que é habitada e animada por clássicos, assim como esses são universais na medida em que traduzem, encarnam, representam a cultura humana.

A cultura de massa, essencialmente uma cultura industrializada e de mercado - tanto mercantil, em sua face prática, quanto mercadológica, no que diz respeito à ideologia que secreta e às mentalidades e inconscientes que constitui e modela - incorpora e processa elementos de culturas étnicas, mas nem por isso adquire caráter universal; não vai além da internacionalização e da globalização, pois os elementos que toma das culturas étnicas são os já adaptados ao seu padrão - o da cultura de massa -, são já produzidos ou préfabricados para integrá-la, frequentemente despersonalizados, carregando e carreando muito pouco da substância, por assim dizer, da cultura étnica original: como resultado, para o consumo e o entretenimento das massas, tudo se assemelha a tudo, tudo forma exatamente na dimensão formal - uma massa homogênea, tudo se submete a uma ideologia e fala uma mesma língua, em termos de valores (inclusive e sobretudo os monetários), venha de onde vier - da Ásia, da África, das Américas, da Oceania -, assim como os comportamentos, no nível antropológico de modo de vida, se uniformizam por todo o planeta sob a égide, a conformação e a configuração massivas promovidas pelo mercado globalizado e globalizante (pense-se nos adolescentes, padronizados até no modo de falar, além do vestuário, do gestual, do comportamento em geral e dos "sonhos de consumo").

É no seio da cultura humana que as culturas étnicas podem ter e têm efetivamente lugar, mantendo, preservando, nutrindo e manifestando suas identidades e mesmo singularidades, pois a cultura humana é universal nesse sentido e nessa dimensão de constituir-se em ambiente e palco do contato, do diálogo, do concerto e mesmo do congraçamento das culturas particulares, na medida inclusive em que essas culturas particulares carregam em si, entre seus elementos formadores, matrizes da cultura universal. Que se veja, ou melhor, que se ouça o exemplo muito próximo de nós - e talvez tão óbvio que chega a ser esquecido ou desconsiderado - de Villa-Lobos, em cujas Bachianas J. S. Bach se faz presente de forma seminal, justamente como um modelo clássico, deixando sua marca a um tempo fundamental, geral e universal no próprio modo de compor, na própria forma - a da tocata, a da fuga, etc. - e até na técnica, no tratamento da harmonia e do contraponto, tudo isso dando expressão a ritmos e formas que ocorrem 
no território nacional, colhidos, trabalhados, transformados pelo compositor brasileiro, com seu estilo igualmente próprio e peculiar.

A universalidade do clássico e da cultura humana refere-se, quantitativamente, à humanidade como o conjunto dos indivíduos e grupos humanos, mas acima de tudo concerne, qualitativamente, à essência, à natureza do - e de cada - humano. Constitui um paradigma, atravessando o humano como que verticalmente, embora possa se exprimir como um sintagma, um eixo horizontal. Em ambas as acepções, o universal da cultura não cabe em nenhuma classe social e não se pode admitir que seja apropriado por qualquer uma delas; aquela que o faz ou que o fizer não estará mais que usurpando algo que pertence ao humano como, justamente, universal. É nesse sentido que a música de Mozart - ou de qualquer outro clássico da arte musical - não é burguesa: não tanto pelo fato de não ter sido produzida pela burguesia nem porque seus ouvintes não são apenas os burgueses, mas sobretudo porque a cultura que ela constitui e representa não pode ser reduzida ao que é ou seria a "cultura burguesa"10, pois encerra e projeta uma universalidade da qual nem a burguesia nem qualquer outra classe tem o direito de apropriar-se, de dizê-la sua, de exercer sobre ela o arbítrio e o capricho de uma relação de propriedade.

Em resumo, o universal encarnado e representado pela cultura (humana) vai muito além do horizonte da classe social, qualquer que seja, o que pode ser observado concretamente quando se associa a cultura, precisamente em e por sua universalidade, à educação como formação humana. "O pobre não precisa de educação", diz Rousseau ${ }^{11}$; mas tampouco o rico, deve-se acrescentar, caso se trate de uma educação adequada ou conveniente unicamente à sua condição social, pois a educação como formação humana não é necessária nem se presta a formar alguém para que seja ou se torne, estritamente, membro de uma camada socioeconômica ou de uma específica classe social - é necessária, justamente (e tautologicamente), para formar o homem, para tornar alguém capaz de transcender a condição de pertencer a esse ou aquele estrato social, assim como

\footnotetext{
${ }^{10}$ No caso específico da música, seria necessário estabelecer e precisar as características de um padrão musical burguês em termos de composição e de audição, explicitando com igual precisão o que seria uma harmonia burguesa, uma melodia burguesa, um ritmo burguês, um contraponto burguês etc., assim como o modo especificamente burguês de apreciar e avaliar música, de deleitar-se com ela etc...

${ }^{11}$ Cf. ROUSSEAU, Jean-Jacques. Emílio, ou Da Educação. Trad. Sérgio Milliet. 3. ed. Rio de Janeiro: Bertrand Brasil, 1995, p. 29.
} 
de enfrentar as vicissitudes inerentes à passagem de uma classe a outra, sobretudo quando a segunda é inferior à primeira ${ }^{12}$.

Lembre-se aqui o exemplo do escritor e linguista sardo Gavino Ledda, que, se se restringisse e se resignasse à formação oferecida por sua classe ou condição social, permaneceria "um pastor e camponês para o resto da [...] vida" ${ }^{13}$, reproduzindo o sistema patriarcal, mera engrenagem na e da sociedade tradicional: não chegaria à consciência da necessidade de socializar seu "eu das cavernas"14, não seria - não se tornaria - o autor de Pai Patrão. Se, por outro lado, quisesse passar de sua classe para outra, convertendo-se de cordeiro que era em leão, segundo as metáforas que encontra em seu próprio meio ${ }^{15}$, bastar-lhe-ia continuar no Exército e contentar-se com uma instrução de nível ginasiano, não precisando dedicar-se a traduzir textos gregos e latinos nem estudar Literatura italiana $^{16}$.

Como se costuma dizer - de maneira muito burguesa, aliás -, toda essa cultura artística não passa de perfumaria: um burguês que lê Virgílio não é, só por isso, mais burguês ou

\footnotetext{
${ }^{12}$ Rousseau, no trecho citado, argumenta inicialmente que o pobre "não precisa de educação" porque "é obrigatória a de sua condição", obrigatoriedade que se traduz e se explicita em necessidade na frase seguinte: "não poderia ter outra" educação a não ser essa. Essa relação obrigatória e necessária entre o pobre e sua educação define-se e delimita-se, nesse passo, em termos de conveniência e adequação, como o autor indica ao tratar, na sequência, da educação do rico: a que ele "recebe de sua condição é a que menos lhe convém tanto para si mesmo quanto para a sociedade". Em resumo, a "condição" do pobre lhe proporciona uma educação que lhe convém, enquanto que a do rico não. $\mathrm{O}$ argumento que se segue altera o sentido inicial ao introduzir a categoria de educação natural e a observação segundo a qual é mais frequente alguém empobrecer-se do que enriquecer, sendo então "menos razoável educar um pobre para ser rico do que um rico para ser pobre". Entram em cena, nesse ponto, o valor e o fim da educação voltada à formação humana, não restrita à condição socioeconômica: trata-se de educar para formar o homem, não especificamente - e restritamente - o pobre e o rico: escolhendo educar o rico, "teremos certeza, ao menos de formar um homem a mais, ao passo que um pobre pode tornar-se homem sozinho". Para a indagação sobre como é possível a um pobre tornar-se homem por sua própria conta, pode-se extrair do contexto a resposta segundo a qual o pobre, por sua própria condição, não precisa ser preparado para a circunstância ou contingência de empobrecer, como sói acontecer aos ricos. Sob tal raciocínio percebe-se outra ideia tácita, que provê a ligação entre o social e o humano: em tal perspectiva, ser humano (conforme uma natureza humana) consiste em (e pressupõe) estar preparado para a vicissitude do empobrecimento, para a queda de uma condição social a outra, inferior àquela, o que sugere que, para Rousseau, o pobre, por sua condição, está mais próximo que o rico daquilo que seria próprio do que o autor considera como sendo a natureza humana.

${ }^{13}$ Cf. LEDDA, Gavino. Pai Patrão \& Recanto. 3. ed. Trad. Liliana Laganá e Ivan Neves Marques Júnior. São Paulo: Berlendis \& Vertecchia Editores, 2008, p. 208.

${ }^{14}$ Ibidem, p. 233.

${ }^{15}$ Ibidem, p. 262-263. Gavino escreve uma carta a seu pai, Abramo, comunicando-lhe a intenção de deixar o Exército e prosseguir "os estudos até a licenciatura": "Você mesmo, desde que eu era menino, em Baddevrustana, me falava sempre de cordeiros e de leões. Muito bem, agora sei exatamente quem são. Você me falava dos leões como de gente feliz: aqui de fato são todos felizes, a começar dos carnívoros menores, os sargentos. Porém eu, de acordo com a sua moral, deveria ser pelo menos uma raposa, circundada por rebanhos e galinheiros. Mas, ao contrário, sinto-me um herbívoro obrigado a comer carne."

${ }^{16}$ Ibidem, p. 262. O filme homônimo dirigido pelos irmãos Taviani, com alguma licença poética, recria a passagem mostrando o diálogo entre Gavino e o colega Rodolfo (que frequentara estudos clássicos no liceu Galileu Galilei, em Florença, até o segundo ano) em meio a exercícios de artilharia: pilotando carros de combate, comunicam-se entre si recitando e traduzindo versos da Eneida, de Virgílio.
} 
menos burguês - o contato com a cultura não afeta sua condição de classe, não interfere em seu ser burguês -, ele seria apenas, em seus próprios termos, um burguês "perfumado", talvez membro de uma elite cultural e intelectual que na voz vulgar costuma ser estereotipada e preconceituosamente tachada de burguesa porque são minoria, entre os que a ela acedem, os de origem não burguesa. É fato essa elite ser majoritariamente composta por membros oriundos da burguesia, que aliás não perdem essa identidade de origem mesmo quando fazem discursos antiburgueses ou se apresentam como se o fossem eles próprios. Isso, porém, não confere a essa elite, essencialmente, um caráter de classe, ou, dizendo melhor, não caracteriza nem define sua essência como burguesa, especificamente, ou classista, de modo geral, a não ser que, de uma maneira bastante simplista e redutora, se conceba e se entenda seu papel, em todo o caso e para todos os efeitos, como funcionalmente consentâneo e servil aos interesses, aos valores e mentalidade(s) da burguesia ou duma determinada classe social, e que a cultura que é não só a matéria e o alimento dessa elite mas o ambiente no qual ela imerge não seja universalmente humana, mas restrita, atrelada e subordinada ao viés de uma classe social, seja ela a burguesia, seja outra qualquer.

É para ser e tornar-se humano que serve e é necessária essa educação pela cultura, tomada propriamente em seu caráter ou dimensão universal, irredutível e rebelde a clivagens e apropriações classistas. E o que justifica efetivamente a existência e a permanência da escola, na medida mesma em que ela se apresenta - ainda que formalmente, ainda que legalmente - como uma instituição que persegue e procura garantir essa formação, a não ser possibilitar ${ }^{17} \mathrm{o}$ desenvolvimento de um Gavino pela e na cultura, descortinando-lhe o mundo de clássicos como Virgílio e Mozart ${ }^{18}$ ?

O que seria e/ou deveria ser, em tal contexto, uma educação pelos clássicos? Teria talvez de ser, antes e ao mesmo tempo, uma educação para os clássicos, uma vez que é preciso educar para que sejam compreendidos e fruídos. Essa educação, porém, não é

\footnotetext{
${ }^{17}$ Também para Calvino (op. cit., p. 13), a existência da escola se justifica pelo fato de propiciar condições: ela "deve fazer com que você conheça bem ou mal um certo número de clássicos dentre os quais (ou em relação aos quais) você poderá depois reconhecer os 'seus' clássicos. A escola é obrigada a dar-lhe instrumentos para efetuar uma opção: mas as escolhas que contam são aquelas que ocorrem fora e depois de cada escola." Explicitem-se as duas ideias que aí aparecem em oposição ao ramerrão destilado ordinariamente contra o ensino escolar: 1) a escola não obriga, mas oferece a cada um as possibilidades e as oportunidades para escolher o "seu" clássico; 2) é a escola que é obrigada a apresentar um acervo que, como um leque de alternativas, torne viáveis as opções individuais.

${ }^{18}$ A música mencionada na autobiografia de Ledda (p. 277), "tão doce quanto amargo era o fel que roía todo o [...] ser" do pai (que não admitia que o filho permanecesse em sua casa e se permitisse, além disso, ouvir o rádio em sua presença), toma a forma, na transposição cinematográfica, do segundo movimento do concerto para clarineta de W. A. Mozart.
} 
exterior, não é um treinamento, nem mesmo a aprendizagem de um know how (do tipo "como ler os clássicos", ou ainda "como gostar de ler os clássicos"), porque envolve e implica o próprio clássico e o próprio aprendiz, em sua sensibilidade, por seus sentidos. O ponto de passagem de uma educação a outra não é nítido, nem talvez definido: educase para os clássicos já por meio - e mesmo através - dos clássicos, ou seja, atravessandoos, penetrando-os, ao mesmo tempo em que se os frequenta, se os absorve, se é penetrado e atravessado por eles.

Em suma, é na medida em que frequentamos os clássicos que aprendemos a compreendê-los e a fruí-los; é na medida em que nos deixamos abarcar, compreender por eles, que nos tornamos íntimos deles, que podemos então, por nossa vez, abarcá-los, compreendê-los.

\section{V}

Um clássico é seminal, modelar, paradigmático, o que significa que costuma servir de referência (e reverência), fonte de inspiração e de imitação. Em suas ocorrências na linguagem comum, a palavra "clássico" implica quase sempre uma hierarquização de avaliações, uma escala de valores. A publicidade de mercadorias pressupõe a noção ao diferenciar entre o que é e o que não é “uma brastemp". Se essa hierarquização, praticada no dia a dia, é estendida até mesmo a objetos a respeito dos quais não parece apropriada, por que não pode ser aplicada justamente no campo em que cabe com toda a propriedade - o das avaliações e validações estéticas?

Um clássico é um marco, no sentido de ser representativo de um estilo de época, de uma forma artística, de todo um gênero, por vezes. Nessa medida, é dele que provêm os parâmetros para julgar e avaliar as obras que fazem parte do estilo, da forma, do gênero: o clássico representa, em tal caso, o ápice da perfeição alcançado no estilo, na forma ou no gênero que ele representa, não raramente ultrapassando-os, extrapolando-os, como ocorre, por exemplo, com Bach e Beethoven, que não só levaram ao máximo desenvolvimento os estilos de época em que se inscreveram - o Barroco e o Romântico, respectivamente - como foram além deles, alargando os horizontes estéticos da arte musical. Isso o clássico faz em sua singularidade, sua especificidade, na tensão entre o estilo de época e o seu estilo próprio, que manifesta sua essência. O clássico necessariamente tem estilo, ele se define por ter - e ser - todo um estilo: ele tanto possui quanto é seu estilo de um modo tão acentuado e significativo que, justamente, esse estilo se torna paradigmático, atua como modelo para gerações ao longo dos séculos; seu risco 
é o de reduzir-se a uma maneira, até um maneirismo, se meramente imitado e reproduzido por epígonos.

No entanto, o clássico não é universal porque se inscreve num cânone; talvez o inverso seja verdadeiro, na medida em que não há mais uma tradição a sustentar e a impor autores e obras tidos como clássicos. Quando um punhado de habitantes de Kinshasa, capital da República Democrática do Congo, toma livre e espontaneamente a iniciativa de reunir-se para constituir uma orquestra sinfônica e um coral e ensaiar e apresentar a nona sinfonia de Beethoven ${ }^{19}$, não o faz por imposição ou cumprimento de um cânone (o qual, aliás, nem faz parte de sua cultura local), mas num espaço caracterizado pelo fim da tradição, no sentido arendtiano de um legado disposto e disponível sem testamento, que se traduz num patrimônio e numa aparelhagem culturais sem instruções de uso $^{20}$.

Nesse aspecto, o clássico, sem prejuízo de sua condição de marco cultural, de sua posição proeminente e paradigmática, não se confunde com o cânone, na proporção em que pode ser constantemente (re)interpretado e (re)avaliado à luz de parâmetros novos ou outros, os quais emanam dele mesmo, graças à sua capacidade de se reinventar, de criar os valores que compõem ou comporão seu contexto: não é um ponto fixo, um referencial fundado e instituído de uma vez por todas mediante uma interpretação e/ou validação estabelecida(s) categoricamente, ortodoxamente, canonicamente. O clássico não é uma estrela morta vagando num espaço vazio; ao contrário, é uma estrela que os corpos e mentes orbitam, recebendo sua luz em diferentes comprimentos de onda.

$\mathrm{Na}$ vida e na lida culturais, o clássico não só se distingue do canônico como, não raramente, a ele se opõe. O canônico comporta a consagração, a sacralização do clássico à medida que envolve sua cristalização numa leitura ${ }^{21}$ que pretende ser, muitas vezes, sua reprodução fiel, seu retrato fotográfico, e não vai além de imitar seu brilho e sua substância - é como se fosse um simulacro de lapidação, que não toca na pedra bruta, a qual se mantém no viço e no esplendor de sua pureza. O canônico é a projeção de imagens estereotipadas, que dispensam a compreensão do clássico, de modo que o que se classifica e se difunde como cânone acaba sendo, para todos os efeitos, um desfile de fantasmas prestigiosos, desfile que raramente leva o espectador a entrar em contato com o clássico

\footnotetext{
${ }^{19}$ Cf. KINSHASA Symphony. Direção: Claus Wischmann e Martin Baer. Produção: Stefan Pannen e Holger Preusse. Roteiro: Claus Wischmann. Elenco: membros da Orquestra Sinfônica Kimbanguista. Duração: 95 min. Ano de produção: 2010.

${ }^{20}$ Cf. ARENDT, Entre o passado e o futuro, p. 40.

${ }^{21} \mathrm{O}$ que se costuma oferecer (e tenta se impor como) canônico é certa interpretação de um clássico - ou melhor, a interpretação tida e havida como a (mais) certa.
} 
em sua qualidade essencial de ente vivo ${ }^{22}$, de pedra bruta sempre à espera de lapidação, porquanto toda e qualquer interpretação ${ }^{23}$ jamais esgota um clássico, jamais dá conta de apropriar-se inteiramente dele, por conseguinte jamais consegue lapidá-lo por inteiro, justamente resguardando sua inteireza ${ }^{24}$. Inesgotável como a própria vida, o clássico independe e prescinde das interpretações e apropriações estritamente canônicas, ou consagradoras: pode-se criticar e atacar um clássico, e ele persiste; pode-se destruí-lo, esfarelá-lo, e ele revive, pois sua condição, ou mesmo sua natureza, é tal que, se é criticado, atacado, destruído, é porque é um clássico ${ }^{25}$, mais do que o contrário.

Essa diferença é reconhecível nas leituras que passam ao largo e/ou se dão mesmo à revelia do cânone e do que ele significa em termos de sacralização e imposição - por exemplo, quando um musicista e compositor popular toma conhecimento de um Bach ou de um Beethoven e (re)conhece nele justamente um clássico (na forma de um criador ou inventor genial), ou quando um homem "comum" como um motorista de táxi lê Platão desapercebido ou sem fazer caso de todo o entorno acadêmico em que ele se insere (ou costuma ser inserido) e que constitui sua aura canônica. Nessas leituras percebe-se o quanto e como o clássico vive e vibra com um entusiasmo e uma expressão que podem até ser ingênuos e rudimentares, mas que não padecem do pernosticismo estéril e muito menos do eruditismo árido providos não raramente pelo canônico.

$\mathrm{Na}$ academia, tende-se a inverter a relação entre o clássico e o cânone, entendendo-se que a obra é clássica porque é canônica. Na realidade viva - ou seja, na vida cultural trata-se do contrário: uma obra torna-se canônica porque é clássica. Mas tornar-se canônico, no caso do clássico, não deveria implicar sua sacralização, ainda que signifique sua inclusão como leitura obrigatória, pois a obrigação de estudar um clássico pressupõe

\footnotetext{
${ }^{22} \mathrm{O}$ que, no caso dos livros, remete ao reparo e à advertência de Calvino (op. cit., p.12) a respeito de "uma inversão de valores muito difundida segundo a qual a introdução, o instrumental crítico, a bibliografia são usados como cortina de fumaça para esconder aquilo que o texto tem a dizer e que só pode dizer se o deixarmos falar sem intermediários que pretendam saber mais do que ele."

${ }^{23}$ Calvino (ibidem, p. 12) recomenda expressamente "a leitura direta dos textos originais, evitando o mais possível bibliografia crítica, comentários, interpretações. A escola e a universidade deveriam servir para fazer entender que nenhum livro que fala de outro livro diz mais sobre o livro em questão; mas fazem de tudo para que se acredite no contrário."

${ }^{24}$ Nos termos de Calvino (ibidem, p. 12): "Um clássico é uma obra que provoca incessantemente uma nuvem de discursos críticos sobre si, mas continuamente a repele para longe".

${ }^{25}$ Um clássico, assinala Calvino (ibidem, p. 13), "pode estabelecer uma relação igualmente forte de oposição, de antítese. Tudo aquilo que Jean-Jacques Rousseau pensa e faz me agrada, mas tudo me inspira um irresistível desejo de contradizê-lo, de criticá-lo, de brigar com ele. Aí pesa a sua antipatia particular num plano temperamental, mas por isso seria melhor que o deixasse de lado; contudo não posso deixar de incluí-lo entre os meus autores."
} 
justamente a abertura para os múltiplos vieses e interpretações envolvidos em sua exploração.

\section{VI}

Quando se considera a interdependência entre o clássico e a cultura, observa-se que cada clássico não só constitui uma cultura - que podemos dizer, até certo ponto, sua como pressupõe uma cultura, da qual depende para brotar e vicejar: pode-se dizer que só constitui sua cultura na medida em que se nutre da cultura na qual e da qual surge. Pensese no clássico, em tal caso, como o antecedente que dá sustentação ao novo e, portanto, à evolução de um processo histórico - seja artístico, seja científico. Recorde-se o exemplo de Isaac Newton, que disse ter chegado ao patamar em que chegou por haver se alçado sobre ombros de gigantes, que o precederam.

A cena coetânea, contudo, não dá senão um quadro bidimensional da cultura no que respeita a essa evolução, pois os traços dela ficam apagados ou na sombra. Daí a necessidade de conhecer os clássicos para obter uma perspectiva tridimensional. $\mathrm{O}$ conhecimento e a frequentação dos clássicos possibilitam uma visão em perspectiva e em profundidade de uma cultura - aí incluídas tanto a arte quanto a ciência -, abrindo espaço e projetando um horizonte para a percepção da linha evolutiva em que se situam os autores, com suas relações de dependência e de hierarquia, de ascendência e descendência, etc.

Inversa e reciprocamente, é necessário considerar não só esse entorno cultural mas também a trama de relações inerentes à cultura do clássico - a que ele constitui e representa - para estudá-lo e tentar compreendê-lo. Como, por exemplo, aproximar-se do sentido que Rousseau ${ }^{26}$ atribui à palavra "pátria" sem levar em conta as leituras que faz e os diálogos que trava com outros clássicos, como Platão e Plutarco? De resto, como compreender Rousseau, de modo geral, sem levar em conta, em alguma medida, os clássicos que leu? Esses outros clássicos, com os quais um clássico dialoga, são, de modo geral, ao mesmo tempo menos e mais que os autores, obras e teorias que os pesquisadores de hoje, sobretudo nas áreas da Filosofia e das Ciências Humanas, adotam, invocam e utilizam como "referenciais teóricos". Menos: porque não desempenham o papel de coordenada, parâmetro ou baliza para a pesquisa, um guia-mestre a ser seguido obedientemente, sob risco de se cair em incoerência ou mesmo em heresia. Mais: porque

\footnotetext{
${ }^{26}$ Cf. Rousseau, Emílio, p. 14.
} 
se prestam a ser a fonte na qual se mata a sede de ideias e ideais que operam como influxos inspiradores, ou aqueles gigantes a cujos ombros se pode subir para ver mais longe.

Sem prejuízo de sua condição de ápice de sua ciência ou de sua arte, ou de um estilo, uma forma ou gênero, o clássico, quando tomado como objeto de estudo, não pode ser isolado, sem mais, desse contexto - da cultura em geral tanto quanto de "sua" cultura, a que ele propicia e enseja. Nesse sentido, faz mais justiça ao clássico a leitura meio espontânea, meio descomprometida, até diletante, mas em todo o caso inteligente, que faz aquele que detém um juízo crítico que lhe faculta reconhecer, discernir e hierarquizar relações culturais, do que a leitura que se orienta por uma perspectiva e uma preocupação de especialista, cujo risco está em tomar o clássico simultaneamente como um fim em si mesmo, hipostasiando o cânone, e como um meio - meio justamente de uma especialização erudita, que usa o clássico como pretexto para exibir o funcionamento de sua aparelhagem sofisticada, o uso de seu arsenal hermenêutico. $\mathrm{O}$ ar pedante que exala desses estudos especializados é o índice intencional e deliberado da busca e da captura da aura prestigiosa do clássico, que esse tipo de estudo faz brilhar - fazendo questão, é claro, de atribuir esse brilho a si mesmo.

$\mathrm{O}$ viés de especialista sujeita-se a atender à tendência e mesmo à tentação de tratar e projetar o clássico como ícone, que é a forma que o cânone assume no âmbito do mercado e da cultura de massa, substancializada na figura estereotipada do gênio. Clássico icônico, o gênio, nesse caso, não é aquele que se alça sobre os ombros de gigantes, mas o que alcança o pódio dos vencedores da corrida para o sucesso, abstraída tal corrida dos fracassos, frustrações, sofrimentos, erros e perdas que costumam marcar e amargar as existências dos gênios de carne e osso em suas concretas condições.

O especialista procede como um técnico, orientando e restringindo seu interesse e a seleção de materiais e conteúdos pelos critérios de uso, utilidade e serventia. Ele trabalha e explora seu objeto de estudo e pesquisa como um minerador ${ }^{27}$, esquadrinhando e escavando apenas a parte do solo cultural de que pode extrair aquilo que seus critérios qualificaram e classificaram antecipadamente como usável, útil, servível, o que pressupõe ignorar e/ou desconsiderar todo o contexto ou entorno cultural que, à primeira - ou, na

\footnotetext{
${ }^{27}$ À diferença de um geólogo ou um arqueólogo que explora o solo no que ele oferece - e é passível de ser recolhido - em termos de sinais e indícios de seu passado, interpretando seus significados tanto na dimensão espacial, pelas relações que entretêm com outros elementos, quanto na temporal, pelo que revelam da presença e da existência dos que compartilharam o mesmo espaço.
} 
verdade, nenhuma ${ }^{28}$ - vista, é pouco ou nada pertinente ao tema eleito, imprestável para os objetivos da pesquisa.

O viés técnico expõe assim a face imediatista do especialista ${ }^{29}$, nesse sentido de que ele só se interessa por aquilo que, em termos de serventia, guarda relações imediatas, no tempo e no espaço da cultura, com seu objeto de estudo: antes de mais nada, mune-se de técnicas e métodos a fim de aplicá-los no recorte do solo cultural que ele, em seguida, passa a escavar para dele extrair somente a parte que lhe é útil, segundo os critérios e parâmetros adotados. Isso ocorre mesmo quando a teoria - ou, mais concretamente, o referencial teórico - que é a base e/ou a fonte de tais critérios e parâmetros técnicometodológicos advoga como princípios a interdisciplinaridade ${ }^{30}$ ou (mais chique...) a transdisciplinaridade, ou ainda pressupõe, implica e incentiva o trânsito do pesquisador, mesmo a título de erudição ${ }^{31}$, pelos mais amplos espectros da cultura.

Compare-se o procedimento do especialista com a atitude do diletante. Esse é alguém como o leitor que se vê entrar numa livraria e perguntar por obras de um certo autor, porque leu um de seus livros, gostou e quer ler outros. Já o especialista, técnico que é, começa por selecionar uma obra do autor e levanta seu estado da arte como quem faz a sondagem do terreno e demarca o solo para dar início à sua exploração extrativista. Certamente não deixará de ler outras obras do mesmo autor, assim como outros autores, mas sempre dentro dos limites condicionados ou determinados pela perspectiva metodológica adotada, pelo referencial teórico assumido, deixando de lado de antemão a possibilidade e a chance de "ver com olhos livres", de abrir-se para leituras múltiplas, ou de encetar e empreender leituras abertas, não predestinadas a desembocar numa interpretação igualmente predeterminada, conformada à perspectiva teóricometodológica.

\footnotetext{
${ }^{28}$ Uma vez que os critérios adotados não possibilitam que sequer seja percebido.

${ }^{29} \mathrm{Ou}$, como escreve Kujawski, a "estreiteza mental do especialista, que conta um por um os pelos da cauda da raposa, mas jamais viu a raposa por inteiro." Cf. KUJAWSKI, Gilberto de Mello. O que é ser intelectual? In: $\quad$. O sabor da vida. Brasília: Letraviva, 1999, p. 142.

${ }^{30}$ Não é raro (ao contrário, é bem frequente) que pesquisadores que fazem praça de tais princípios incorram, em suas pesquisas, exatamente nas limitações apontadas pelas teorias adotadas, desconsiderando ou relevando um tipo de contradição que, se ocorresse no plano moral, significaria hipocrisia. Já na dimensão cultural, à luz de um humanismo cujo influxo não deixa de se fazer presente na constituição daquelas teorias (segundo o princípio e o valor, por exemplo, do "nada do que é humano me é indiferente"), a contradição reveste-se do aspecto de uma aberração.

${ }^{31}$ Kujawski assinala que a "propriedade dominante" da erudição é "a extensão, no sentido de que procura abranger número cada vez maior de dados, cumulativamente". Cf. KUJAWSKI, Gilberto de Mello. Erudição e cultura. In: . O sabor da vida. Brasília: Letraviva, 1999, p. 24.
} 
É certo que o diletante não leva qualquer vantagem relevante nesse confronto, mas se suas leituras não são condicionadas nem dirigidas exclusiva ou predominantemente por um comportamento-reflexo de demanda por mero entretenimento, se elas mergulham ou pelo menos dispõem-se a mergulhar nas obras, tomando-as como suas interlocutoras, detentoras de conhecimentos e verdades seminais para a formação cultural, ele não recortará a obra e o autor do contexto ou entorno cultural mais amplo, não delimitará nem restringirá o terreno de sua leitura, mas deixará que ela coloque à mostra os laços que obra e autor revelam possuir com outros autores e obras, assim como o campo em que se situam ou em que são classificados comunica-se com outros campos, mesmo que distantes, mesmo que não pareçam ter qualquer pertinência ${ }^{32}$.

\section{VII}

Aprender, principalmente quando se trata das artes, consiste em descobrir e mesmo inventar lições onde outros não o fizeram ou não foram capazes de fazê-lo. O mestre de uma arte é em parte inventado, na medida em que os pósteros veem no que fez e deixou, algo a aprender, algo que não está óbvio. Nesse sentido, o discípulo, o aprendiz, é que faz o mestre, no momento mesmo em que se assume como discípulo, aprendiz do que vê e reconhece, pela obra, como um grande artista.

Alguns clássicos, como artistas, tiveram fama de revolucionários - como Beethoven, que induziu toda uma mudança de sensibilidade. Mas como mestres em suas artes, os clássicos são revolucionários permanentes, pois têm sempre algo novo a ensinar, isto é, aquele que os toma como mestres e se dispõe a aprender com eles sempre descobre algo novo a aprender ${ }^{33}$. Isso independe da opinião da época histórica em que viveu o artista: J.

S. Bach era, em seu tempo, considerado um compositor antiquado e ultrapassado.

Se a lição explícita do clássico costuma se cristalizar em cânone, a natureza do clássico é justamente a de transcender o canônico, na medida em que traz em seu bojo, potencialmente, lições outras, que estão à espera de seus discípulos e aprendizes - os

\footnotetext{
32 Pode-se pensar, a propósito, no diletantismo atribuído a Philippe Ariès. Ele abriu novas sendas: "Ainda não estava em voga a história das mentalidades, e nosso franco-atirador há muito percorria terras virgens e vencia algumas batalhas das quais era a única testemunha." Ele "falava de tudo, mas sem nunca preconizar, admitindo suas contradições, rindo das críticas que lhe dirigiam, um riso modesto, de que poucos são capazes". Elucidou temas que "enriquecem os programas do concurso para a cátedra, mesmo com a prudência acadêmica, em nome da qual é sempre melhor falar do sexo dos anjos que do sexo dos homens, das relações internacionais que das relações sentimentais e das estratégias políticas que do amor, do acaso e da morte". Cf. Michel Winock, Prefácio. In: ARIÈS, Philippe. Um historiador diletante. Trad. Ana Luíza Dantas Borges. Rio de Janeiro: Bertrand Brasil, 1994, p. 9-11.

${ }^{33}$ No que respeita à Literatura: "Um clássico é um livro que nunca terminou de dizer aquilo que tinha para dizer" (cf. Calvino, op. cit., p. 11).
} 
quais se definem precisamente por descobrir e/ou inventar essas lições no diálogo vivo, no confronto corpo a corpo com a obra e/ou o autor -, lições que não raramente subvertem os esquemas canônicos ou neles revelam inconsistências através das quais se descortinam riquezas outras do clássico, que o atualizam e o tornam mais vivo, culturalmente, neutralizando e superando a tendência de petrificação ou fossilização a que leva a pura e simples veneração canônica.

E embora o debate sobre o clássico costume se dar em ambientes acadêmicos, o aprender com ele extrapola em muito esses ambientes, na proporção em que as questões que apresenta, propõe ou suscita são vitais: retomemos o princípio de que o clássico, em última análise, tem a ver com a vida - a vida cultural, mais especificamente, mas no sentido de que a cultura, em tal aspecto, abarca e abraça a vida, sobretudo pelo lado mais fundo ou significativo, o da condição humana. A lição que temos ou podemos ter de um clássico - ainda que ele não tivesse originalmente a intenção ou a pretensão de oferecêla - é o fato de que ele sempre desvela, revela, ilumina e/ou dá voz a algum aspecto da condição humana.

\section{VIII}

"Sou um dramaturgo: mostro/ o que vou vendo", assim Bertolt Brecht inicia sua Canção do Dramaturgo, de $1935^{34}$. A boa - a chamada grande - obra de arte literária, seja, como nesse exemplo de Brecht, no teatro e na poesia, seja na prosa, distingue-se por deter e exercer essa virtude de mostrar, que se desdobra no desvelar e no revelar, ou seja, no mostrar o que se oculta ou, pelo menos, não está à vista de todos, ou ainda o que está à vista de todos mas só é percebido por uns poucos. Ao exercício dessa virtude, aliás, é que a obra deverá o ser considerada ou não digna de merecer o epíteto de grande, o qualificativo de boa ou excelente.

É não só evidente como inevitável e até necessário que esse mostrar, esse desvelar ou revelar se dê a partir de um ponto de vista, pois o artista da palavra - o escritor - é não só um ser humano, situado humanamente no mesmo nível dos demais, sujeito à mesma humana condição, em sua essência, mas também um ente histórico e um indivíduo social, sendo-lhe impossível abstrair esse contexto, ou abstrair-se dessa sua situação históricosocial e elevar-se a uma posição que lhe faculte e confira o ponto de vista estratosférico de um deus.

\footnotetext{
${ }^{34}$ Apud WILLETT, John. O teatro de Brecht. Trad. Álvaro Cabral. Rio de Janeiro: Zahar, 1967, p. 105.
} 
Assim, se ele mostra as grandezas e misérias de seu tempo, se revela seus esplendores e mazelas, se desvela tanto o sorriso quanto as entranhas da sociedade que habita, não pode fazê-lo senão a partir dos lugares e perspectivas em que se tem e/ou se coloca. Contudo, tanto por causa quanto a despeito dessa visada em situação, concreta, a grande obra de arte literária não só preserva e mantém como exerce e vive a ambiguidade, a ambivalência, enfim, a polissemia que expõe - como fratura exposta, de fato - o que o artista viu e observou, o que ele tem e se dispõe a mostrar, a desvelar, a revelar. Pensese, por exemplo, na Antígona de Sófocles: a ambiguidade da peça (que consiste em abraçar e sustentar os pontos de vista opostos e conflitantes de Creonte e Antígona, ao mesmo tempo em que dividir-se entre eles) não é simplesmente a do poeta, do dramaturgo, do artista - uma ambiguidade pessoal e particular -, mas da época e da sociedade, e, no final das contas, da própria condição humana.

Frequentemente, quem lê tais obras com o intuito premeditado de nelas caçar detalhes e manifestações que the permitam acusar e condenar o autor por crimes vários, tais como racismo, machismo (ou sexismo), homofobia etc., confunde as instâncias de autor, narradores e personagens, desconsidera e descontextualiza as referências históricas e sociais, praticando uma pseudoleitura que ignora até mesmo a tentação historiográfica de tomar a obra de arte como documento, e não chega sequer a ser uma pré-leitura, ou seja, uma preparação ou disposição de penetrar no universo da obra para decifrá-lo, interpretálo, tentar compreendê-lo: o pseudoleitor fica, com efeito, no vestíbulo, na antessala da leitura, não porém predisposto a fazê-la; no lugar, fica cuspindo preconceitos e impropérios contra e sobre a obra, detendo-se na pronúncia de sua sentença, etapa preparatória para a execução das penas impostas à obra e a seu autor.

Que ganho de conhecimento proporciona tal pseudoleitura, a que ela conduz em termos de compreensão da obra e de seu autor, em que medida permite que mostrem o que têm para mostrar? Certamente, revela mais acerca do censor que da coisa censurada e, se é sintomática de um gesto coletivo, escancara o tipo de pobreza ou indigência cultural que assola uma época, que calha de ser a nossa. E é provável que aquele que mostrar, desvelar e/ou revelar em sua obra esse gesto, essa indigência, venha a ser sério candidato a tornar-se clássico.

\section{IX}

Um clássico não é dono da verdade, tampouco seu porta-voz. Se ele é lido e compreendido justamente como um clássico, isto é, como uma obra aberta e em progresso 
- o que significa que a própria leitura se realiza como obra aberta e em progresso -, ele inspira e expira o socrático vento do pensamento ${ }^{35}$. Por outras palavras, o que caracteriza uma obra clássica, do ponto de vista da busca da verdade, é essa condição de ser atravessada pelo vento do pensamento - é esse vento que pode ser haurido na leitura do clássico, é ele que, por essa leitura, atravessa nossas mentes, arejando-as, (re)vitalizando nossos espíritos. Inspirando e expirando também, por nossa vez, esse vento, menos e, ao mesmo tempo, mais que encontrar ou desvelar a verdade, somos animados pela leitura do clássico a ouvir, tomar e portar suas palavras como linha e anzol para pescar o que não é palavra $^{36}$, assim como a sentir e pesar no silêncio do que não é palavra a incomensurabilidade e o mistério daquilo para o qual o clássico aponta, daquilo que sua leitura por vezes deixa entrever, assim como, por vezes, escancara.

O próprio movimento dessa leitura, insuflada pelo vento do pensamento, a conduz ou deve conduzi-la - para além da interpretação e da produção de comentários, ainda que bastante eruditos, bastante minuciosos e complexos, enriquecidos e encorpados por teorias hermenêuticas altamente sofisticadas, sobre as ideias e doutrinas do clássico. A leitura fiel a esse fluxo aventura-se na discussão sobre o estatuto de verdade do logos que, por esse esforço de interpretação, sopra do clássico, podendo avançar para um filosofar autônomo que, tomando ou não o clássico como referência, tateia nas trevas do real, nos interstícios entre a linguagem e o absurdo, entre o que é palavra e o que não o é.

\section{$\mathbf{X}$}

Aproximar um clássico de um estudante não significa nem deve significar unicamente, numa pedagogia de "jardinagem”, levar húmus para a planta, pois o clássico, no caso, não representa própria ou precipuamente a terra fértil e fertilizante, mas uma outra planta, mais antiga e frondosa, cuja relação com a planta mais nova não está estabelecida e muito menos determinada de antemão: a planta mais nova pode não tirar nenhum proveito dessa relação se não se interessar, se não se voltar e não se dedicar a essa relação, se nela não investir esforço, empenho, labuta.

Por outro lado, essa relação lhe poderá ser até danosa, apesar de aparentemente proveitosa, se a planta não tirar justamente proveito dessa companhia para crescer, limitando-se a vegetar à sombra da planta maior. Não basta, portanto, que a relação entre

\footnotetext{
${ }^{35}$ Cf. ARENDT, Hannah. A vida do espírito. Trad. Cesar Augusto de Almeida, Antônio Abranches e Helena Martins. Rio de Janeiro: Civilização Brasileira, 2009, p. 196.

${ }^{36}$ Cf. LISPECTOR, Clarice. Água viva. Rio de Janeiro: Rocco, 1998, p. 21.
} 
a planta nova e a planta secular, que traz consigo a seiva de antigos saberes, seja interessada; é preciso que haja um diálogo entre elas, o que exige como precondição e pressuposto que a planta nova compartilhe - e tire proveito - do solo comum, da cultura constituída pelo entorno do clássico, solo em que o clássico se enraíza, sem o qual não sobrevive, e que a planta jovem deve trazer para si, alargando seu perímetro de modo a caber nele, a envolver-se nele também, por sua vez.

Essa cultura é a mesma que, para a massa e seus mentores ou aproveitadores, não passa do que chamam de "cultura inútil". Esse juízo de valor, com a atitude que lhe corresponde, é certamente uma das engrenagens da "estranha máquina de entortar homens" a que SaintExupéry faz alusão no final de Terra dos homens ${ }^{37}$, e um sintoma que explica por que "não há jardineiros para os homens" - mesmo porque, para que existissem, seria preciso que houvesse solo propício à cultura dos clássicos. E se, como termina dizendo o mesmo autor, "Só o Espírito, soprando sobre a argila, pode criar o Homem"38, o desafio não está "simplesmente" em adubar uma terra para nela plantar; está em (re)criar a própria terra.

Trata-se do trabalho de toda uma ascese, semelhante à da alma no processo maiêuticoplatônico que implica a progressiva abstração do objeto, passando do nível do sensorial e do emocional para o inteligível e o espiritual. Nesse caso, não só os primeiros passos, ainda muito chãos, muito rentes ao corpo, portanto dados no meio cultural mais imediato e imediatista (normalmente o da cultura de massa, voltada ao entretenimento), mas também os passos intermediários, que pressupõem o alçar-se a um nível de relacionamento e cultivo da cultura em que se apresentam e se fixam como procedimentos o estudo e o prazer estético ${ }^{39}$, também esses passos intermediários são ultrapassados, tratados como meio, para se chegar a uma posição de autonomia: continua-se a pensar e a criar com os clássicos, mas de forma autônoma, justamente criativa, no interior desses limites dados pela cultura (dos clássicos). É num sentido semelhante que o espírito da espécie pode fecundar cada potencial de artista ou pensador, como sugere Saint-Exupéry.

Para tal ascese, a cultura constitui ao mesmo tempo ambiente propício e meio ingrato, o que significa que ela nunca se completa de modo a que o ascético possa de fato libertar-

\footnotetext{
${ }^{37}$ Cf. SAINT-EXUPÉRY, Antoine de. Terra dos homens. Trad. Rubem Braga. São Paulo: Círculo do Livro, s.d., p. 162.

${ }^{38}$ Ibidem, p. 163.

${ }^{39}$ Prazer que vai bem além do entretenimento e que, infelizmente, costuma ser confundido com ele em e por certas pedagogias que defendem o "aprender brincando", aparentemente inscientes de que esse tipo de aprendizado não leva automaticamente nem induz (a)o aprender no nível do prazeroso, degrau que pressupõe justamente o aprendizado, corporal inclusive, do prazer estético, o qual por sua vez compreende a frequentação dos clássicos, num relacionamento que propicia ou pode proporcionar o gozo de tal prazer.
} 
se do carnal e ascender plenamente ao espiritual, como atestam - se não escancaram - as patéticas vicissitudes e patológicas contradições de Erika Kohut ${ }^{40}$, a protagonista do romance de Elfried Jelinek, A pianista, apontando para as limitações ou o fracasso, até, do que Freud chama de sublimação. É de se duvidar ${ }^{41}$ que, na maioria dos casos, esse processo, pelo qual "instintos são levados a deslocar, a situar em outras vias as condições de sua satisfação", tornando "possível que atividades psíquicas mais elevadas, científicas, artísticas, ideológicas, tenham papel tão significativo na vida civilizada" 42 , seja efetivo e eficaz. Em seu papel de "olho da lei" 43 , a mãe de Erika comunga com esse ideal civilizatório, ao mesmo tempo em que lamenta que ele não seja de fato perseguido, como o narrador do romance explicita com seu tom irônico, tragicomicamente jocoso:

A mãe acha que, ao contrário do que se diz por aí a respeito da vida desregrada dos artistas, o melhor que um artista tem a fazer é esquecer sua sexualidade. E, se não for capaz, será simplesmente humano, mas não pode ser simplesmente humano. Pois então não será divino! Infelizmente as biografias dos artistas, que afinal são o que há de mais importante sobre eles, estão frequentemente repletas dos desejos e das astúcias sexuais de seus protagonistas. E elas criam a impressão errônea de que os pepinos da boa sonoridade só crescem sobre a podridão do composto da sexualidade. ${ }^{44}$

Seja como for, quem, concretamente, se volta para a cultura e nela se enfurna, morre para a vida comum, dedicada à satisfação do corpo massificado, via mercado. Essa morte, aparência de uma existência em estado mineral, cultivada e vivida no interior da cultura,

\footnotetext{
${ }^{40}$ A professora de piano Erika Kohut, que não chega a enveredar pela criação artística, como compositora, nem por uma carreira de concertista, entrega-se à busca solitária de satisfação sexual na prática do voyeurismo assim como à automutilação: "Seu hobby é cortar o próprio corpo". (Cf. JELINEK, Elfried. A pianista. Trad. Luis S. Krausz. São Paulo: Tordesilhas, 2011, p. 60-67; 101-103.)

${ }^{41}$ No caso de Erika Kohut, é de fato "impossível não ver em que medida a civilização é construída sobre a renúncia instintual, o quanto ela pressupõe justamente a não satisfação (supressão, repressão, ou o quê mais?) de instintos poderosos" (cf. FREUD, Sigmund. O mal-estar na civilização. Trad. Paulo César de Souza. 1. reimpr. São Paulo: Penguin Classics; Companhia das Letras, 2012, p. 43). No entanto, isso é o mesmo que sublimação?

${ }^{42}$ Cf. FREUD, Sigmund. $O$ mal-estar na civilização, p. 42. Lembre-se, a propósito, que o autor não faz questão de distinguir entre civilização e cultura, como assinala em outra obra, O futuro de uma ilusão: "Como se sabe, a cultura humana - me refiro a tudo aquilo em que a vida humana se elevou acima de suas condições animais e se distingue da vida dos bichos; e eu me recuso a separar cultura e civilização - mostra dois lados ao observador. Ela abrange, por um lado, todo o saber e toda a capacidade adquiridos pelo homem com o fim de dominar as forças da natureza e obter seus bens para a satisfação das necessidades humanas e, por outro, todas as instituições necessárias para regular as relações dos homens entre si e, em especial, a divisão dos bens acessíveis." (Cf. FREUD, Sigmund. O futuro de uma ilusão. Trad. Renato Zwick; revisão técnica e prefácio de Renata Udler Cromberg; ensaio biobibliográfico de Paulo Endo e Edson Sousa. Porto Alegre, RS: L\&PM, 2011, p. 22.)

${ }^{43}$ Cf. Jelinek, op. cit., p. 224.

${ }^{44}$ Ibidem, p. 223. Reprimindo a filha, levando-a a sacrificar a vida sexual em favor da arte (no caso, a música), a mãe de Erika desempenha papel oposto ao que Freud, em O mal-estar na civilização (p. 48-49), atribui às mulheres em geral, quando sustenta que, "através das exigências de seu amor", vão contra "a corrente da civilização e exercem a sua influência refreadora e retardadora", adotando "uma atitude hostil" ante a cultura na medida em que se veem relegadas a segundo plano pelos homens, os quais, por seu turno, eximir-se-iam de deveres matrimoniais e familiares para darem conta de suas tarefas culturais "mediante uma adequada distribuição da libido", uma vez que não dispõem de "quantidades ilimitadas de energia psíquica".
} 
é um retirar-se, um poupar-se frente à outra morte, essa sim mecanizada (dada e reproduzida continuamente pela "máquina de entortar homens"), aparentando vida na medida em que se presta a atender às necessidades biofisiológicas dos corpos. A morte implicada naquela retirada é a existência na ordem da imensidão e do vazio oceânicos, é o navegar que se opõe ao viver por viver, é a pesquisa sem lastro e sem termo dos sentidos do viver.

\section{Referências}

ALI, Monica. Um lugar chamado Brick Lane. Trad. Léa Viveiros de Castro. Rio de Janeiro: Rocco, 2004.

ARENDT, Hannah. O conceito de História - antigo e moderno. In: . Entre o passado e o futuro. Trad. Mauro W. Barbosa de Almeida. São Paulo: Perspectiva, 1972, p. 69-126.

O que é Autoridade? In: . Entre o passado e o futuro. Trad. Mauro W.

Barbosa de Almeida. São Paulo: Perspectiva, 1972, p. 127-187.

. A vida do espírito. Trad. Cesar Augusto de Almeida, Antônio Abranches e Helena Martins. Rio de Janeiro: Civilização Brasileira, 2009.

ARIÈS, Philippe. Um historiador diletante. Trad. Ana Luíza Dantas Borges. Rio de Janeiro: Bertrand Brasil, 1994.

CALVINO, Italo. Por que ler os clássicos. In: . Por que ler os clássicos. Trad. Nilson Moulin. 5. reimpr. São Paulo: Companhia de Bolso, 2016, p. 9-16.

FREUD, Sigmund. O mal-estar na civilização. Trad. Paulo César de Souza. 1.reimpr. São Paulo: Penguin Classics; Companhia das Letras, 2012.

. O futuro de uma ilusão. Trad. Renato Zwick; revisão técnica e prefácio de Renata Udler Cromberg; ensaio biobibliográfico de Paulo Endo e Edson Sousa. Porto Alegre, RS: L\&PM, 2011.

Jelinek, Elfried. A pianista. Trad. Luis S. Krausz. São Paulo: Tordesilhas, 2011.

Kinshasa Symphony. Direção: Claus Wischmann e Martin Baer. Produção: Stefan Pannen e Holger Preusse. Roteiro: Claus Wischmann. Elenco: membros da Orquestra Sinfônica Kimbanguista. Duração: 95 min. Ano de produção: 2010.

KUJAWSKI, Gilberto de Mello. Erudição e cultura. In: . O sabor da vida. Brasília: Letraviva, 1999, p. 17-25. 139-145. O que é ser intelectual? In: . O sabor da vida. Brasília: Letraviva, 1999, p. 
LEDDA, Gavino. Pai Patrão \& Recanto. 3. ed. Trad. Liliana Laganá e Ivan Neves Marques Júnior. São Paulo: Berlendis \& Vertecchia Editores, 2008.

LISPECTOR, Clarice. Água viva. Rio de Janeiro: Rocco, 1998.

PAI Patrão. Direção: Paolo e Vittorio Taviani. Produção: Giuliani G. De Negri, Radio Televisione Italiana (RAI). Roteiro: Paolo e Vittorio Taviani. Elenco: Omero Antonutti, Saverio Marconi, Marcella Michelangeli, Fabrizio Forte, Pierluigi Alvau, Fabio Angioni, Giuseppino Angioni, Giuseppe Brandino, Nanni Moretti. Título original: Padre Padrone. Duração: 114 min. Ano de lançamento: 1977.

ROUSSEAU, Jean-Jacques. Emílio, ou Da Educação. Trad. Sérgio Milliet. 3. ed. Rio de Janeiro: Bertrand Brasil, 1995.

SAINT-EXUPÉRY, Antoine de. Terra dos homens. Trad. Rubem Braga. São Paulo: Círculo do Livro, s.d.

SHAKESPEARE, William. O Mercador de Veneza. Trad. F. Carlos de Almeida Cunha Medeiros e Oscar Mendes. In: . Obra completa v. II, p. 437-497. Rio de Janeiro: Nova Aguilar, 1989.

WILLETT, John. O teatro de Brecht. Trad. Álvaro Cabral. Rio de Janeiro: Zahar, 1967. 